\author{
I. Istadi (Editor-in-Chief) \\ Department of Chemical Engineering, Diponegoro University,E-mail: istadi@che.undip.ac.id
}

DOI: 10.9767/bcrec.11.2.565.v-vii

Bulletin of Chemical Reaction Engineering \& Catalysis (ISSN 1978-2993) is an international journal published by Department of Chemical Engineering, Diponegoro University, jointly with Masyarakat Katalis Indonesia - Indonesian Catalyst Society (MKICS). In Scopus coverage years 2011-2015, this journal ranked 42nd (Q4 level) in Scimago Catalysis category and ranked 30 th (Q4 level) in Scimago Process and Chemistry Technology category. In addition, this journal has also good impact factor in Scimago Journal Ranking / Journal Metrics (SJR $=0.192$; SNIP $=0.477 ;$ IPP $=0.533$ ) for coverage years 2011-2015. Since 2015, this journal has also been listed in Master Journal List of Thomson Reuters-Web of Science (Emerging Source Citation Index), and under evaluation to be indexed in Science Citation Index (Thomson Reuters - Web of Science). Thank you for great contribution to all respectful Authors, Peer-reviewers, and Editors.

This issue (BCREC, Volume 11, Issue 2, Year 2016 (August) has published 16 articles. The published articles come from Original Research Articles and selected articles from an international conferences, The International Conference on Fluids and Chemical Engineering (FluidsChE 2015) (http://fluidsche.ump.edu.my/index.php/en/) (Malaysia, 25-27 November 2015) after selected and reviewed by Scientific Committee of the conferences and by Peer-Reviewers of this journal consecutively. This issue was authored and co-authored by 60 authors from 6 countries (Indonesia, Russia, Malaysia, Algeria, India, and China).

In this issue, there are three articles focused on biodiesel production using heterogeneous catalysis process [1-4]. Catalytic hydrodeoxygenation of fatty acids for biodiesel production was studied by Stephacheva et al. [1], while Kumar et al. [2] focused on SrO-MBCUS agglomerates for esterification and transesterification of high FFA vegetable oil. The $1 \%-\mathrm{Pd} / \mathrm{C}$ had the highest specific surface area compared with 5\%-Pd/C which reach up to $97.5 \%$ selectivity and $100 \%$ conversion of substrate. Meanwhile, when using Musa Balbisiana Colla Underground Stem (MBCUS) as catalyst, the biodiesel so prepared had identical characteristics to that with MBCUS alone, but at a lower temperature $\left(200^{\circ} \mathrm{C}\right)$ and internal vapour pressure. Metal leaching was much lower while reusability of the catalyst was enhanced. It was also confirmed that the particle size has little impact upon the conversion efficacy, but the basic active sites are more important. Another study, Abidin et al. [3] found that calcium loaded on deoiled spent bleaching clay was promising as a solid base catalyst for waste cooking oil transesterification. The catalyst shows high activity under optimum condition of 5 hours of reaction time, $12: 1$ of methanol to oil molar ratio with 7 wt.\% of catalyst. The transesterification yields $84.7 \%$ methyl ester. Therefore, this catalyst has potential to be used in the transesterification of waste cooking oil in producing biodiesel due to its high activity. Another article was focused on fish bone-catalyzed methanolysis of waste cooking oil [4]. The highest yield of biodiesel, $86 \%$ were achieved at $6 \mathrm{wt} \%$ of catalyst amount, mixing of $300 \mathrm{rpm}$, methanol to oil ratio of 18:1 and reaction temperature of $65^{\circ} \mathrm{C}$. The activation energy (Ea) was $34.12 \mathrm{~kJ} / \mathrm{mol}$. This study also proves that transesterification process is not affected by the internal mass transfer due to the Thiele modulus value between $0-1.69$.

Another article focused on $\mathrm{TiO}_{2}$-based catalysts were conducted by Permadani et al. [5] and Mei et al . [6]. The composite of $\mathrm{ZrO}_{2}-\mathrm{TiO}_{2}$ produced from local zircon sand as a photocatalyst for the degradation of methylene blue in a single batik dye wastewater was studied by Permadani et al. [5]. The composite of $\mathrm{ZrO}_{2}-\mathrm{TiO}_{2}$ produced from local zircon sand was used as a photocatalyst for the degradation of methylene blue in a single batik dye wastewater [5]. The addition of $\mathrm{ZrO}_{2}$ into $\mathrm{TiO}_{2}$ is able to increase the photocatalytic activity proven by $88.75 \%$ degradation of $\mathrm{MB}$ at a $\mathrm{ZrO}_{2}-\mathrm{TiO}_{2}$ weight ratio of 1:1. 
Meanwhile, the $\mathrm{V}_{2} \mathrm{O}_{5}$ catalysts which supported on nano-scale $\mathrm{TiO}_{2}$ with variation of vanadium contents $(5 \%, 10 \%, 20 \%$ and $40 \%)$ were studied by Mei et al. [6]. The characterization results showed that the phase structure of $\mathrm{V}_{2} \mathrm{O}_{5}$ supported on $\mathrm{TiO}_{2}$ depends heavily on the vanadium contents, which will put great effects on the catalytic performances for soot oxidation. The consistency of pyrolysis kinetics and TG experimental results confirm that the best activity catalyst is V20 in discussed catalysts which is nearest to the monolayer dispersion saturated state of $\mathrm{V}_{2} \mathrm{O}_{5} / \mathrm{TiO}_{2}$ catalyst.

There are two articles which focused on Montmorillonite Clay (Maghnite-H+) studies, they are by Medjdoub \& Mohammed [7] and Abdelkader \& Mohammed [8]. In the first paper, a new synthetic method has been developed to produce HACTP using friendly, green, ecologic and non toxic catalyst clay as proton source, the support catalyst Maghnite-H+. The use of non toxic solvent make this an attractive way for the synthesis of hexa(allylamino)cyclotriphosphazene [7]. Another article, cationic polyacrylamide (CPAM) was synthesized via free solvent cationic polymerization under microwave irradiation and it's exfoliation ability has been evaluated in MMT-acide suspension. It was demonstrated that structure and thermal stability of cationic composite polyacrylamide depend on the ratio of monomer/clay and the temperature optimized [8].

A preliminary study on esterification of free fatty acids (FFA) in artificially modified feedstock using ionic liquids as catalysts was studied by Roslan et al. [9]. They found that $\mathrm{BMIMHSO}_{4}$ shows considerable potential to reduce the FFA in the feedstock as it is exhibit excellent catalytic activity due to lower alkyl chain of $\mathrm{BMIMHSO}_{4}$ compared to $\mathrm{HMIMHSO}_{4}$.

Other studies were focused on catalyst synthesis suitable for hydrogen and synthesis gas production [10-14]. The catalysts were palladium promoter on Ni-based catalysts [10], carbon dioxide dry reforming of glycerol for hydrogen production using $\mathrm{Ni} / \mathrm{ZrO}_{2}$ and $\mathrm{Ni} / \mathrm{CaO}$ catalysts [11], $\mathrm{Co} / \mathrm{CeO}_{2}$ catalyst [12], Ag-promoted $\mathrm{Ni} / \mathrm{SiO}_{2}$ catalyst [13], and $\mathrm{Ni} / \mathrm{Al}_{2} \mathrm{O}_{3}$ catalyst [14].

Some researchers studied effect of calcination temperature on performance of photocatalytic reactor system for seawater pretreatment [15]. The Ti:Ash catalyst that calcined at $500{ }^{\circ} \mathrm{C}$ was found to be the most effective catalyst in the desalination of seawater by reducing the salt concentration of more than $9 \%$ compared to Ti:Ash calcined at $800{ }^{\circ} \mathrm{C}$. It can be concluded that catalyst calcination at 500 ${ }^{\circ} \mathrm{C}$ has better character, performance and economically feasible catalyst for seawater desalination. The last article was focused on kinetic and thermodynamics of methylene blue adsorption onto zero valent iron supported on mesoporous silica [16]. They found that the performance of NZVI/MSNs as adsorbent was examined by adsorption of methylene blue (MB), performed in series of batch experiments. In the kinetic studies, the pseudo second order equation provided the best fit with the experimental data. Thermodynamic studies indicated that the adsorption process is endothermic.

Currently, BCREC journal is an open access international journal under licensed of a Creative Commons Attribution-ShareAlike 4.0 International License. Therefore, readers can read and download any full-text articles for free of charge. Official website address of BCREC journal is: http://bcrec.undip.ac.id. Editor would like to appreciate and to call for papers all researchers, academicians, industrial practitioners focused on chemical reaction engineering and catalysis to contribute to this international journal.

\section{Cited to:}

[1] Stepacheva, A.A., Sapunov, V.N., Sulman, E.M., Nikoshvili, L.Z., Sulman, M.G., Sidorov, A.I., Demidenko, G.N., Matveeva, V.G. (2016). Catalytic Hydrodeoxygenation of Fatty Acids for Biodiesel Production. Bulletin of Chemical Reaction Engineering \& Catalysis. 11(2): 125-132

[2] Kumar, P., Sarma, A.K., Bansal, A., Jha, M.K. (2016). Formulation of SrO-MBCUS Agglomerates for Esterification and Transesterification of High FFA Vegetable Oil. Bulletin of Chemical Reaction Engineering \& Catalysis. 11(2): 140-150 


\section{Available online at BCREC Website: http://bcrec.undip.ac.id}

Bulletin of Chemical Reaction Engineering \& Catalysis, 11 (2), 2016, vii

[3] Abidin, R.Z., Maniam, G.P., Rahim, M.H.A. (2016). Transesterification of Waste Cooking Oil using Calcium Loaded on Deoiled Spent Bleaching Clay as A Solid Base Catalyst. Bulletin of Chemical Reaction Engineering \& Catalysis. 11(2): 176-181

[4] Sulaiman, S., Amin, M.H.M. (2016). Fish Bone-Catalyzed Methanolysis of Waste Cooking Oil. Bulletin of Chemical Reaction Engineering \& Catalysis. 11(2): 245-249

[5] Permadani, I., Phasa, D.A., Pratiwi, A.W., Rahmawati, F. (2016). The Composite of $\mathrm{ZrO}_{2}$-TiO $\mathrm{Ti}_{2}$ Produced from Local Zircon Sand as A Photocatalyst for The Degradation of Methylene Blue in A Single Batik Dye Wastewater. Bulletin of Chemical Reaction Engineering \& Catalysis. 11(2): 133-139.

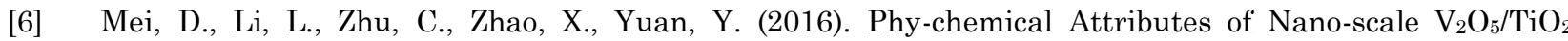
Catalyst and Its' Effect on Soot Oxidation. Bulletin of Chemical Reaction Engineering \& Catalysis. 11(2): 161-169

[7] Medjdoub, L., Mohammed, B. (2016). New Method for Nucleophilic Substitution on Hexachlorocyclotriphosphazene by Allylamine Using an Algerian Proton Exchanged Montmorillonite Clay (Maghnite-H+) as a Green Solid Catalyst. Bulletin of Chemical Reaction Engineering \& Catalysis. 11(2): 151-160

[8] Abdelkader, R., Mohammed, B. (2016). Green Synthesis of Cationic Polyacrylamide Composite Catalyzed by An Ecologically Catalyst Clay Called Maghnite-H+ (Algerian MMT) Under Microwave Irradiation. Bulletin of Chemical Reaction Engineering \& Catalysis. 11(2): 170-175

[9] Roslan, N.A., Che Hasnan, M.H., Abdullah, N., Abdullah, S.B., Abidin, S.Z. (2016). A Preliminary Study: Esterification of Free Fatty Acids (FFA) in Artificially Modified Feedstock Using Ionic Liquids as Catalysts. Bulletin of Chemical Reaction Engineering \& Catalysis. 11(2): 182-190

[10] Mei, I.L.S., Lock, S.S.M., Vo, D.V.N., Abdullah, B. (2016). Thermo-Catalytic Methane Decomposition for Hydrogen Production: Effect of Palladium Promoter on Ni-based Catalysts. Bulletin of Chemical Reaction Engineering \& Catalysis. 11(2): 191-199

[11] Arif, N.M.M., Vo, D.V.N., Azizan, M.T., Abidin, S.Z. (2016). Carbon Dioxide Dry Reforming of Glycerol for Hydrogen Production using $\mathrm{Ni} / \mathrm{ZrO}_{2}$ and $\mathrm{Ni} / \mathrm{CaO}$ as Catalysts. Bulletin of Chemical Reaction Engineering \& Catalysis. 11(2): 200-209

[12] Ayodele, B.V., Khan, M.R., Cheng, C.K. (2016). Production of CO-rich Hydrogen Gas from Methane Dry Reforming over $\mathrm{Co} / \mathrm{CeO}_{2}$ Catalyst. Bulletin of Chemical Reaction Engineering \& Catalysis. 11(2): 210-219

[13] Harun, N., Gimbun, J., Azizan, M.T., Abidin, S.Z. (2016). Characterization of Ag-promoted Ni/SiO 2 Catalysts for Syngas Production via Carbon Dioxide $\left(\mathrm{CO}_{2}\right)$ Dry Reforming of Glycerol. Bulletin of Chemical Reaction Engineering \& Catalysis. 11(2): 220-229

[14] Shahirah, M.N.N., Ayodele, B.V., Gimbun, J., Cheng, C.K. (2016). Samarium Promoted Ni/Al $\mathrm{O}_{3} \mathrm{Catalysts}$ for Syngas Production from Glycerol Pyrolysis. Bulletin of Chemical Reaction Engineering \& Catalysis. 11(2): 238-244

[15] Kan, W.E., Roslan, J., Isha, R. (2016). Effect of Calcination Temperature on Performance of Photocatalytic Reactor System for Seawater Pretreatment. Bulletin of Chemical Reaction Engineering \& Catalysis. 11(2): 230-237

[16] Hameed, A.K., Dewayanto, N., Dongyun, D., Nordin, M.R., Mohd Hasbi Ab. Rahim, M.H.A. (2016). Kinetic and Thermodynamics of Methylene Blue Adsorption onto Zero Valent Iron Supported on Mesoporous Silica. Bulletin of Chemical Reaction Engineering \& Catalysis. 11(2): 250-261 